\title{
Effects of calcium lonophore A23187 on the apoptosis of hepatic stellate cells stimulated by transforming growth factor- $\beta_{1}$
}

Yanan $\mathrm{Li}^{1}$, Yu Yan${ }^{2}$, Fang Liu', Ming Wang ${ }^{1}$, Fumin Feng ${ }^{1}$ and Yonghong Xiao ${ }^{1 *}$ (D)

* Correspondence:

1619747081@qq.com

'Department of School of Public Health, North China University of Science and Technology, Hebei, Tang Shan 063000, China

Full list of author information is available at the end of the article

\begin{abstract}
Background: Our previous study showed that during in vitro experiments changes in calcium concentration were associated with apoptosis. We presumed that the calcium ion might play a role as intermediate messenger for apoptosis-related genes. No such evidence has been reported in the literature. Here, we investigate the effect of calcium ionophore A23187 on the apoptosis of rat hepatic stellate cells (HSCs) stimulated by transforming growth factor- $\beta_{1}\left(\mathrm{TGF}-\beta_{1}\right)$ to explore the mechanism of apoptosis through the endoplasmic reticulum stress pathway.
\end{abstract}

Methods: The apoptotic rate was determined using flow cytometry. The changes in $\mathrm{Ca}^{2+}$ level in HSCs were examined with laser confocal microscopy. The expressions of caspase-12 GRP78 and caspase-9 were assayed via western blot.

Results: The respective apoptosis rates for the blank group, the TGF- $\beta_{1}$ group and the TGF- $\beta_{1}+$ low, medium and high dose calcium ionophore A23187 groups were 3. $40 \pm 0.10 \%, 1.76 \pm 0.12 \%, 5.86 \pm 0.31 \%, 11.20 \pm 0.48 \%$ and $15.08 \pm 0.75 \%$, with significant differences between the groups $(p<0.05)$. The concentration of $\mathrm{Ca}^{2+}$ and the expression of the GRP78, caspase- 9 and caspase- 12 proteins significantly increased with increasing calcium ionophore A23187 doses $(p<0.05)$.

Conclusion: Calcium ionophore A23187 increased intracellular $\mathrm{Ca}^{2+}$ and activated endoplasmic reticulum stress, which promoted HSC apoptosis.

Keywords: Hepatic fibrosis, Hepatic stellate cells, Calcium ionophore A23187, Apoptosis

\section{() Biomed Central}

\section{Introduction}

Hepatic fibrosis (HF) is a reversible wound-healing response to all etiologies of liver disease, including chronic viral hepatitis, alcohol consumption, fatty liver disease, cholestasis and autoimmune hepatitis [1]. Hepatic stellate cells (HSCs) are central to the development of HF [2].

When HSCs are activated, they transform into myofibroblasts and secrete a large volume of extracellular matrix (ECM). Transforming growth factor beta-1 (TGF- $\beta_{1}$ ) can activate HSCs and increase the expression of various fibrosis factors that playan important role in HF [3].

(c) The Author(s). 2017 Open Access This article is distributed under the terms of the Creative Commons Attribution 4.0 International License (http://creativecommons.org/licenses/by/4.0/), which permits unrestricted use, distribution, and reproduction in any medium, provided you give appropriate credit to the original author(s) and the source, provide a link to the Creative Commons license, and indicate if changes were made. The Creative Commons Public Domain Dedication waiver (http://creativecommons.org/ publicdomain/zero/1.0/) applies to the data made available in this article, unless otherwise stated. 
Promoting $\mathrm{HSC}$ apoptosis can reduce or even reverse $\mathrm{HF}$, and induction of the activation of HSC apoptosis as a therapeutic strategy is a research hotspot [4]. Endoplasmic reticulum stress (ERS) is a recently discovered pathway of apoptosis. It includes the non-folding protein reaction, $\mathrm{Ca}^{2+}$ initiation signals and other ERS-specific mechanisms. It can activate caspase-12 and mediate caspase- 12 cleavage of caspase- 9 and other downstream effects of protease, eventually leading to apoptosis [5].

The endoplasmic reticulum (ER) is the main site of the intracellular $\mathrm{Ca}^{2+}$ reserve and $\mathrm{Ca}^{2+}$ signal transduction [6]. Calcium ionophore A23187 is a calcium mobilizer that plays a critical role in cell apoptosis [7]. Therefore, this study to investigate the effects of calcium ionophore A23187 on the apoptosis of HSC stimulated by transforming growth factor- $\beta_{1}$ to provide a theoretical basis for the treatment of HF.

\section{Materials and methods}

\section{Cell Strains,Cell culture and cell grouping and treatment}

The hepatic stellate cell line CFSC isolated from carbon tetrachloride-stimulated rats was provided by Professor Greenwell from the cell bank of George Washington University in the United States [8].The cells stored in liquid nitrogen were cultured in Dulbecco's modified Eagle's medium (DMEM; BI) supplemented with $6 \%$ fetal bovine serum (FBS; BI), $100 \mathrm{U} / \mathrm{ml}$ penicillin and $100 \mu \mathrm{g} / \mathrm{ml}$ streptomycin in humidified air at $37{ }^{\circ} \mathrm{C}$ with $5 \% \mathrm{CO}_{2}$ (Thermo). When the cells reached $80 \%$ confluence, they were dislodged by trypsinization and seeded in culture bottles. The cells were divided into the following groups: blank, TGF- $\beta_{1}(5 \mathrm{ng} / \mathrm{ml})$, TGF- $\beta_{1}(5 \mathrm{ng} / \mathrm{ml})+$ low,TGF- $\beta_{1}$ (5 ng/ $\mathrm{ml})+$ middle and TGF- $\beta_{1}(5 \mathrm{ng} / \mathrm{ml})+$ high, with low, middle and high referring to the dose of calcium ionophore A23187. The blank group was cultured in DMEM without FBS for $48 \mathrm{~h}$. The TGF- $\beta_{1}$ group was cultured with $5 \mathrm{ng} / \mathrm{ml}$ TGF- $\beta_{1}$ (Glico) for $48 \mathrm{~h}$. The TGF- $\beta_{1}+$ low, middle, and high dose calcium ionophore A23187 groups were cultured with $5 \mathrm{ng} / \mathrm{ml}$ TGF- $\beta_{1}$ to which 1, 2 and $4 \mu \mathrm{M}$ A23187 (Cayman) were added, respectively. The changes to each index were measured after $24 \mathrm{~h}$.

\section{Annexin V/PI analysis of HSC apoptosis rate}

After treatment with A23187, the cells were washed with cold PBS three times, dislodged by trypsinization, centrifuged, and then washed with cold PBS three times. After setting aside the blank group of cells as a negative control, the other groups were resuspended in $195 \mu \mathrm{l}$ of annexin V binding buffer, incubated with $5 \mu \mathrm{l}$ of FITCconjugated annexin V (BD), and mixed gently for $30 \mathrm{~min}$ in the dark. After centrifugation, the supernatant was discarded, the cells were resuspended in $195 \mu \mathrm{l}$ of annexin V binding buffer, incubated with $5 \mu \mathrm{L}$ of propidium iodide (BD), and mixed gently. Finally, the cells were examined using flow cytometry (FACSCalibur).

\section{Cellular $\mathrm{Ca}^{2+}$ imaging and laser scanning confocal microscopy}

The cells were conventionally cultured, dislodged by trypsinization, and seeded into a small dish for confocal microscopy. HSCs were harvested after the appropriate treatment. The culture medium was discarded, the cells were washed with cold PBS three times and incubated with $400 \mu \mathrm{l}$ Fluo-3/AM (KPL) for $40 \mathrm{~min}$ at $37{ }^{\circ} \mathrm{C}$ in the dark. Then the cells were washed with cold PBS three times, $\sim 1 \mathrm{ml}$ culture medium 
was added, and the dish was incubated for $20 \mathrm{~min}$. Changes in cellular $\mathrm{Ca}^{2+}$ were monitored using a laser scanning confocal microscope (FV10i).

\section{Western blot assay for GRP78, C-Caspase-12 and C-Caspase-9 protein expression}

The cells were treated with calcium ionophore A23187 for $24 \mathrm{~h}$, after which the original culture medium was discarded, and the cells were washed with cold PBS twice or three times. The culture dish was set on ice and $\sim 200 \mu \mathrm{l}$ cell lysis buffer was added (Protease inhibitor: RIPA $=1: 250$ ). The cells were adequately cleaved for $10-30 \mathrm{~min}$ and then centrifuged $\left(12,000 \mathrm{r} / \mathrm{min} ; 4^{\circ} \mathrm{C}\right)$ for $15 \mathrm{~min}$.

A BCA Protein Assay kit (MultiSciences) was used to determine the protein concentration. The cells were boiled for $5 \mathrm{~min}$ at $100{ }^{\circ} \mathrm{C}$ and stored at $-20{ }^{\circ} \mathrm{C}$. A $10 \%$ SDS-PAGE gel preparation kit (Beyotime Biotechnology) was used to assay GRP78 and caspase-9 protein expression. After blocking, the turn wet method was used to transfer the cells to PVDF membrane and then GRP78 (1:1000; Arigo), C-caspase-12 (1:1000; Arigo) and C-caspase-9 (1:1000; Wuhan) antibodies were added at $4{ }^{\circ} \mathrm{C}$ overnight. The membrane was washed with TBST three times, the secondary antibody was added, and the membrane was incubated at room temperature for about $1 \mathrm{~h}$ and washed with TBST three times. Development used equivalently-mixed ECL luminescence reagents A and B. Images were taken using an E-Gel Imager (Universal Hood II).

\section{Statistical analysis}

Results were described as means \pm SD of at least three independent experiments. Comparisons across time points were performed with one-way analysis of variance to detect the main effect differences using 17.0 SPSS statistical analysis software. Comparison between two means was performed with LSD-t to detect the main effect differences. In all cases, $p<0.05$ was considered to be statistically significant.

\section{Results}

Flow cytometry to determine the apoptosis rate in the treated cells

Flow cytometry was used to determine the apoptosis rate for HSCs (Fig. 1). Comparisons were performed with one-way analysis of variance to detect group differences. The apoptosis rate of the TGF- $\beta_{1}$ group was $1.76 \pm 0.12 \%$, which was lower than that the blank group $(3.40 \pm 0.10 \%)$. The difference was statistically significant $(p<0.05)$. The apoptosis rates of the TGF- $\beta_{1}+$ low, middle and high dose calcium ionophore A23187 groups were respectively $5.86 \pm 0.31 \%, 11.20 \pm 0.48 \%$ and $15.08 \pm 0.75 \%$, with significant differences between the groups $(p<0.05$; Fig. 1f).

\section{Effects of calcium lonophore $\mathrm{A} 23187$ on $\mathrm{Ca}^{2+}$ levels in rat hepatic stellate cells following stimulation with transforming growth factor- $\beta 1$}

Laser confocal microscopy was used to determine the calcium fluorescence in HSCs (Fig. 2). The blank group and TGF- $\beta_{1}$ group presented weak fluorescence in the cytoplasm (Fig. 2a and b; $p>0.05$ ). Adding the calcium ionophore A23187 after TGF- $\beta_{1}$ stimulation led to strong fluorescence $(p<0.05$; Fig. 2c-e). The LSD method showed that the intracellular $\mathrm{Ca}^{2+}$ concentration of the two pairs was statistically significant ( $p$ $<0.05$; Fig. 3). 


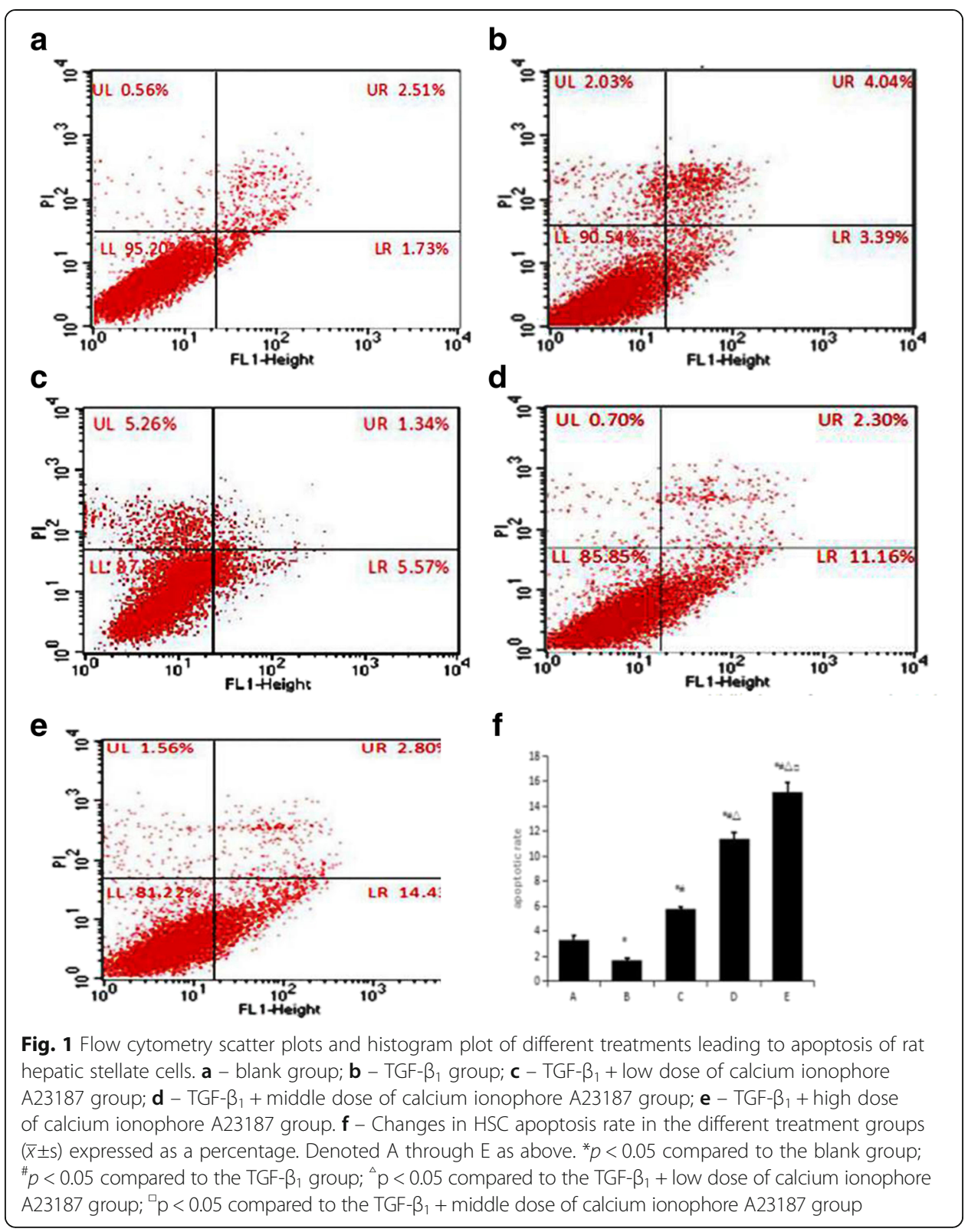

The expression of GRP78, C-caspsase-12 and C-caspase-9 in different treatment groups Protein gel electrophoresis of GRP78 expression in the different treatment groups of HSC (Fig. 4). The mean grey values of GRP78 protein the blank group and the TGF- $\beta_{1}$ group were $0.34 \pm 0.05$ and $0.31 \pm 0.03$, respectively, and the difference was not statistically significant $(p>0.05)$. The mean grey values of the low, middle and high dose calcium ionophore A23187 groups were $0.46 \pm 0.06,0.62 \pm 0.03$ and $0.79 \pm 0.01$, respectively.

As the dose of A23187 increased, the expression of GRP78 protein also increased in the groups, and the differences between the two were statistically significant $(p<0.05$; Fig. 7). The protein gel electrophoresis of C-caspase- 12 in different treatment groups is shown in Fig. 5. When compared to the blank group, C-caspase-12 change in the TGF$\beta_{1}$ group was not obvious $(p>0.05)$. The mean grey values of the low, middle and high 

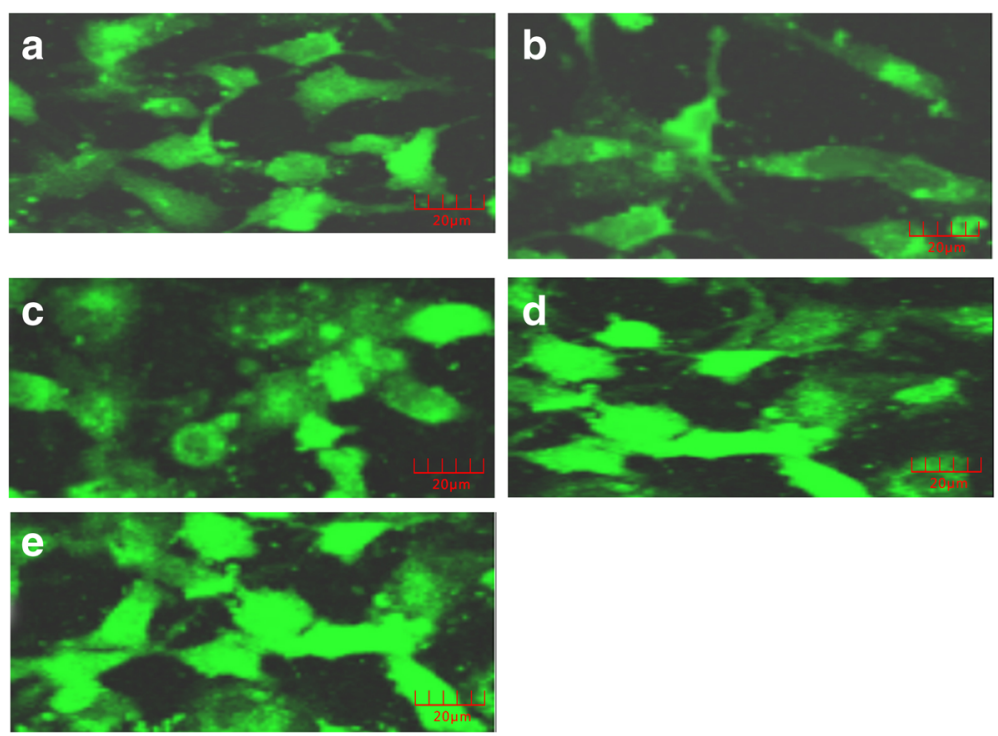

Fig. 2 Laser confocal microscopy images of the changes in $\mathrm{Ca}^{2+}$ fluorescence intensity. a - blank group; b - TGF- $\beta_{1}$ group; $\mathbf{c}, \mathbf{d}$ and $\mathbf{e}-$ TGF- $\beta_{1}+$ low, middle and high dose of calcium ionophore A23187 groups

dose calcium ionophore A23187 groups were $0.48 \pm 0.03,0.66 \pm 0.06$ and $0.90 \pm 0.03$, respectively. As the dose of $\mathrm{A} 23187$ increased, the expression of $\mathrm{C}$-caspase-12 protein also increased in the groups, and the differences between the two were statistically significant $(p<0.05)$.

Protein gel electrophoresis of C-caspase-9 expression in the different treatment groups of HSCs is shown in Fig. 6. The mean grey values of C-caspase-9 protein for the blank group and the TGF- $\beta_{1}$ group were $0.34 \pm 0.05$ and $0.30 \pm 0.02$, respectively. The difference was not statistically significant $(p>0.05)$. The mean grey values of the low, middle and high dose calcium ionophore A23187 groups were $0.62 \pm 0.06,0.85 \pm$ 0.08 and $1.21 \pm 0.21$, respectively. As the dose of A23187 increased, the expression of

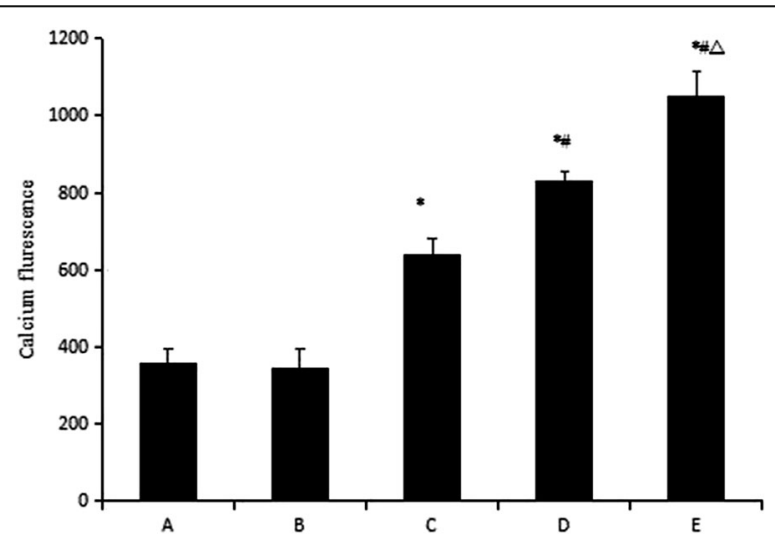

Fig. 3 Effect of different treatments on HSC calcium fluorescence. A - blank group; B - TGF- $\beta_{1}$ group; $C$, D and $\mathrm{E}-\mathrm{TGF}-\beta_{1}+$ low, middle and high dose of calcium ionophore A23187 groups. ${ }^{*} p<0.05$ compared to the blank group; ${ }^{*} p<0.05$ compared to the TGF- $\beta_{1}$ group; ${ }^{\wedge} p<0.05$ compared to the TGF- $\beta_{1}+$ low dose of calcium ionophore A23187 group 


\section{GRP78

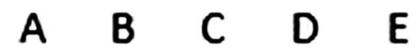 \\ $\beta$-actin

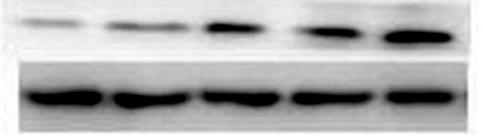 \\ $78 \mathrm{kD}$}

Fig. 4 GRP78 protein expressing in different HSC groups as measured using western blot. A - blank group; $B-$ TGF- $\beta_{1}$ group; $C, D$ and $E-$ TGF- $\beta_{1}+$ low, middle and high dose of calcium ionophore A23187 groups

C-caspase- 9 protein also increased in the groups, and the difference between the two was statistically significant $(p<0.05$; Fig. 7).

\section{Discussion}

$\mathrm{Ca}^{2+}$ is an important secondary messenger in cells. It is involved in the regulation of various physiological functions, such as cell growth, proliferation, differentiation and apoptosis [9]. In the resting state, the intracellular $\mathrm{Ca}^{2+}$ concentration is maintained at a very low level, and is about $1 / 10,000$ of the extracellular $\mathrm{Ca}^{2+}$ concentration. In response to a suitable stimulus, the intracellular $\mathrm{Ca}^{2+}$ concentration increases.

The calcium ionophore A23187 is the chain ion carrier. External lipophilic complexes of $\mathrm{Ca}^{2+}$ A23187 form at a 1:2 ratio, with two molecules of A23187 end-to-end. The transport of $\mathrm{Ca}^{2+}$ is performed by the carrier complex in the membrane. The effect is different in different cells, which indicates that the signal to the channel is also different. For instance, increased $\mathrm{Ca}^{2+}$ as a secondary messenger can promote protein kinase $\mathrm{C}$ and other calcium-dependent protein kinase activation, and catalyze intracellular phosphorylation of various proteins to initiate cell activation and proliferation. A23187 can rapidly increase intracellular $\mathrm{Ca}^{2+}$ concentration in HL-60 cells, disrupting the intracellular $\mathrm{Ca}^{2+}$ steady-state balance to initiate cell apoptosis [10].

To investigate the effect of A23187 on apoptosis in rat HSCs, the cells were stimulated with TGF- $\beta_{1}$. Electron microscopy showed that the cytoplasm had numerous collagen fibers and the nucleus was in the split phase, suggesting that myofibroblasts participated in the development of HF, mainly through their own abnormal proliferation. Furthermore, numerous collagen fibers contain collagen secretion from the extracellular matrix (ECM).

Activated HSCs are the primary source of ECM in HF. They play a key role in its formation and development. TGF- $\beta_{1}$ is the most powerful fibrosis promoting factor that can be used to stimulate HSCs to create a model of HF in vitro. TGF- $\beta_{1}$ can be used for mechanism research into the regulation of HSC gene expression and the potential of related pathways as therapeutic modalities [3].

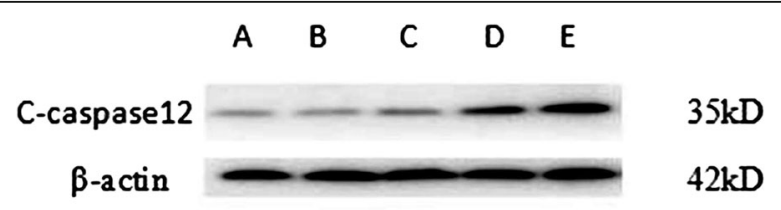

Fig. 5 C-caspase-12 protein expression in the different HSC groups as measured using western blot. A - blank group; B - TGF- $\beta_{1}$ group; $C, D$ and E - TGF- $\beta_{1}+$ low, middle and and high dose of calcium ionophore A23187 groups 


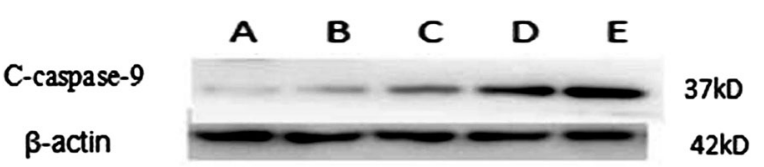

Fig. 6 C-caspase-9 protein in the different HSC groups as measured using western blot. A - blank group; B - TGF- $\beta_{1}$ group; C, D and E - TGF- $\beta_{1}+$ low, middle and high dose calcium ionophore A23187 groups

The cells were stimulated with TGF- $\beta_{1}$ and then different doses $(1,2$ and $4 \mu \mathrm{M})$ of A23187 were added. The effect of A23187 on the apoptotic rate was detected using flow cytometry. The apoptosis rate of HSCs was increased with an increase in calcium ionophore concentration. A23187 can form stable complexes with $\mathrm{Ca}^{2+}$ and open the calcium channel on the cell membrane, leading to increase in intracellular calcium concentration. In this study, Fluo-3/AM-loaded cells exposed to low, middle and high doses of A23187 were used to observe the intracellular $\mathrm{Ca}^{2+}$ steady-state imbalance. $\mathrm{Ca}^{2+}$ elevation could activate the ERS pathway, which could be the cause of apoptosis.

Our study shows that in these HSCs, the intracellular $\mathrm{Ca}^{2+}$ homeostasis was mainly maintained through the endoplasmic reticulum (ER). Various factors can cause changes in $\mathrm{Ca}^{2+}$ channels on the ER, resulting in $\mathrm{Ca}^{2+}$ deprivation or $\mathrm{Ca}^{2+}$ overload and activation of the ERS pathway.

GRP78 is an ERS chaperone that plays an important role in maintaining ER protein synthesis, proper protein folding and intracellular calcium homeostasis. It is also an important marker of ERS [11, 12]. GRP78 plays a key regulatory role in ERS and is an important defense mechanism for cells. In this study, the expression of GRP78 protein was detected via immunoblotting. Different doses of A23187 led to high expression of GRP78 protein, suggesting that intracellular ERS was activated.

$\mathrm{Ca}^{2+}$ initiates an early step in apoptosis, which is closely linked to the ER. ERS has a unique caspase-12 pathway. Caspase-12 belongs to the caspase family and is considered to be a specific apoptotic signal in the ERS apoptotic pathway. It is activated by ERS and can mediate mitochondrial-independent apoptosis [13]. Under normal conditions,

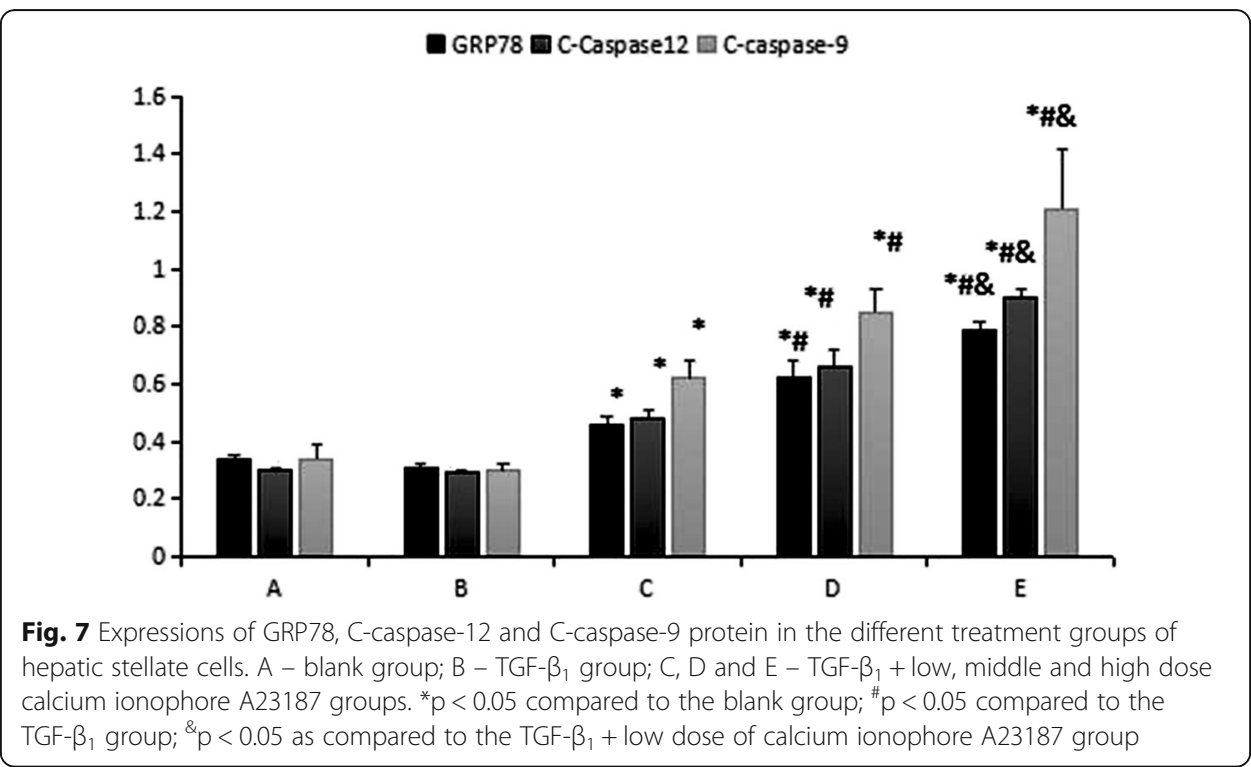


caspase-12 is located on the ER in the form of inactive zymogens. When ERS occurs, IRE1 $\alpha$ activates TRAF2 to activate caspase-12 and caspase-9, causing caspase-mediated apoptosis [14].

Xie et al. [15] induced ER stress in cells of the human hepatocarcinoma cell line Huh-7 with toxic carotene (TG). Western blotting was used to detect procaspase-12, which was found to be significantly associated with TG and apoptosis. Bitko et al. [16] found that apoptosis of A549 human lung epithelial cells caused by respiratory syncytial virus was associated with caspase-12 activation and ERS. Here, we found that low, middle and high doses of A23187 significantly upregulated the expression of intracellular caspase-12 and caspase-9.

\section{Conclusion}

These results suggest that A23187 increases intracellular $\mathrm{Ca}^{2+}$, causing intracellular calcium disorders, and activates the ERS pathway to promote HSC apoptosis.

\section{Abbreviations}

DMEM: Dulbecco's modified Eagle's medium; ECM: Extracellular matrix; ERS: Endoplasmic reticulum stress; HF: Hepatic fibrosis; HSC: Hepatic stellate cell; TGF- $\beta_{1}$ : Transforming growth factor- $\beta_{1}$

\section{Acknowledgements}

Not applicable.

\section{Funding}

This study was supported by the Hebei Province Natural Fund Project.

\section{Availability of data and materials}

The studied cell line was provided by Professor Greenwell from the cell bank of George Washington University in the United States. Any additional information related to this study is available from the author for correspondence upon reasonable request.

\section{Authors' contributions}

YX and FF created the study concept and designed the experiments. YL performed the experiments. YY, MW and LF analyzed the data and wrote the manuscript. All authors read and approved the final manuscript.

\section{Ethics approval and consent to participate}

This study was approved by North China University of Science and Technology.

Consent for publication

Not applicable.

Competing interests

The authors declare that they have no competing interests.

\section{Publisher's Note}

Springer Nature remains neutral with regard to jurisdictional claims in published maps and institutional affiliations.

\section{Author details}

${ }^{1}$ Department of School of Public Health, North China University of Science and Technology, Hebei, Tang Shan 063000, China. ${ }^{2}$ Department of School of Basic Medical Science, North China University of Science and Technology, Hebei, Tang Shan 063000, China.

Received: 25 July 2017 Accepted: 15 December 2017

Published online: 02 January 2018

\section{References}

1. Pereira TN, Walsh MJ, Lewindon PJ. Paediatric cholestatic liver disease:Diagnosis,assessment of disease progression and mechanisms of fibrogenesis. World J Gastrointest Pathophysio. 2010;1(2):69-84.

2. Erkan M, Weis N, Pan Z. Organ-,inflammation- and cancer specific transcriptional fingerprints of pancreatic and hepatic stellate cells. Mol Cancer. 2010;9:88.

3. Zhou W-C, Zhang Q-B, Liang Q. Pathogenesis of liver cirrhosis. World J Gastroenterol. 2014;20(23):7312-24.

4. Weiskirchen R, Tacke F. Cellular and molecular functions of hepatic stellate cells in inflammatory responses and liver immunology. Hepatobiliary Surg Nutr. 2014;3(6):344-63. 
5. Sharma V, Kaur R, Bhatnagar A, et al. Low-pH-induced apoptosis: role of endoplasmic reticulum stress-induced calcium permeability and mitochondria-dependent signaling. Cell Stress Chaperones. 2015;20(3):431-40.

6. Montague K, Malik B, Gray AL, et al. Endoplasmic reticulum stress in spinal and bulbar muscular atrophy: a potential target for therapy. Brain. 2014;137(7):1894-906.

7. Liu Y, Han X-j, Liu M-h. Three-day-old human unfertilized oocytes after in vitro fertilization/intracytoplasmic sperm injection can be activated by calcium lonophore A23187 or strontium chloride and develop to blastocysts. Cell Reprogram. 2014;16(4):276-80.

8. Yonghong $X$, Dianwu L. Effect of transforming growth factor - $\beta 1$ antibody on intracellular calcium concentration in hepatic stellate cells. J FourthMilMed Univ. 2005;26(17):1558-561.

9. Bahar E, Kim H, Yoon H. ER stress-mediated signaling: action potential and Ca2+ as key players. Int J Mol Sci. 2016; 17(9):1558.

10. Yang K, Qiang L, Yaining Z. A23187 induced HL-60 differentiation into dendritic cells. J Sichuan University (Medical Sciences). 2007:38(2):209-12.

11. Axel H. Schönthal.Endoplasmic reticulum stress: its role in disease and novel prospects for therapy. Scientifica (Cairo). 2012:857516.

12. Cho H, Wu M, Zhang L, et al. Signaling dynamics of palmitate-induced ER stress responses mediated by ATF4 in HepG2 cells. BMC Syst Biol. 2013;7(1):9.

13. Sun Y, Liu G, Song T, et al. Upregulation of GRP78 and caspase-12 in diastolic failing hea. Acta Biochim Pol. 2008; 55(3):511-6.

14. Kim EM, Shin EJ, Choi JH, et al. Matrix metalloproteinase-3 is increased and participates in neuronal apoptotic signalingdownstream of caspase-12 during endoplasmic reticulum stress. J Biol Chem. 2010;285(22):16444-52

15. Xie Q, Khaoustov VI, Chung CC, et al. Effect of tauroursodeoxycholic acid on ER stress_induced Caspase-12 activation. Hepatology. 2002;36(3):592-601.

16. Nakagawa T, Zhu H, Morishima N, et al. Caspase-12 mediates ER_specific apoptosis and cytotoxicity by amyloid_ $\beta$. Nature. 2000;403(6765):98-103.

\section{Submit your next manuscript to BioMed Central and we will help you at every step:}

- We accept pre-submission inquiries

- Our selector tool helps you to find the most relevant journal

- We provide round the clock customer support

- Convenient online submission

- Thorough peer review

- Inclusion in PubMed and all major indexing services

- Maximum visibility for your research

Submit your manuscript at www.biomedcentral.com/submit 